\title{
Analysis of Francis Bacon's Prose Writing Style
}

\author{
Javed Sahibzada \\ Senior Assistant Professor \\ English Language and Literature Department \\ Kandahar University \\ Kandahar, Afghanistan \\ E-mail: sahibzada.javed@gmail.com \\ Saifullah Maroofi \\ Assistant Lecturer and Head \\ Dari Language and Literature Department \\ Education Faculty, Kandahar University \\ Kandahar, Afghanistan \\ E-mail: safiullahmaroofi@gmail.com \\ Susan Hussein Laftah \\ Assistance Lecturer \\ Department of English Language and Literature Department \\ Dhi Qar Education Directorate \\ Thi-Qar, Iraq \\ E-mail: samesoul.janI43@gmail.com
}

\begin{abstract}
The purpose of this expositional paper was to analyze the Francis Bacon Prose Style as literary genre with reference to his essays ("Of Studies" Of Revenge" and "Of Marriage and Single Life") Bacon's essays have a certain unique characteristic which make us question the classification of essay. Literary review through expositional form of writing for presenting opinions based on facts from his essays was considered as a method for analyzing literary essays. The finding of this paper through analyzing his three major essays ("Of Studies" Of Revenge" and "Of Marriage and Single Life) revealed, Bacon has used various features which can be termed as: Aphoristic, Paradox, Rhetorical Device, Imagery, Analogy, and allusion for being impersonal trough saving his own personality. Bacon's works are classified as essays for having the artistic value of Beauty and moral. Francis Bacon has distinctive features that fame his works through the ages. Bacon's style is compact yet polished and indeed some of its conciseness is due to the skillful adaptation of Latin idiom and phrase. His sentences are pregnant and have the capability of expending into paragraph. He had a great and impressive mastery over the art of saying maximum into minimum words.
\end{abstract}

Keywords: Bacon, Compact, Distinct, Detached, Francis, Impersonality, Pregnant.

\section{Introduction}

Root of essay is derived from the French word assayer, which means "to attempt," or "to try." An essay is a short form of literary composition centered on a single subject matter, and most often gives the personal opinion of the author. A famous English essayist, Aldous Huxley defines essays as, "a literary device for saying almost everything about almost anything." ("Literary Devices," n.d.). The Oxford Dictionary describes it as "a short piece of writing on a particular subject." we can define it as a scholarly work in writing that provides the author's personal argument. Essays are divided into two types: literary essays and none literary essays, which this expositional paper attempt to focus on second the types. Literary essays are divided into four types (Klarer, 2013).

Expository Essay: In which the writer provides an explanation of theme, issue or idea, to the particular audience which may be various depending on the purpose of author through giving his personal opinions about it. These types of essays are presented through examples, definitions, comparisons, and contrast.

Descriptive Essay: As it can be best interpreted from its name, which gives a description of a particular topic, or describes the qualities and characteristics of something or of a person in detail. It has artistic freedom, and creates images in the minds of readers through the use of imageries or use of the five senses. 
Narrative Essay: Narrative essay is non-fiction, yet it describes a story with its physical descriptions, through which the writer not only tells a story, but also makes a point by providing reasons.

Persuasive Essay: in persuasive essay, the writer tries to convince his/her readers to adopt his position or point of view about any particular issue that is trying attempt to persuade. In these types of essays, the writer provides their audience solid reasoning for a particular issue, where it requires a lot of research to claimed or defend an idea that is why it's also called an argumentative essay.

Nonliterary essays are also having the same types, but they can be written in any format, though they have common similarities which are common to all sort of text: purpose and target audience, content, structure and their own use of language, (Brindle, 2006). They are difference in their purpose and target audience, content, structure and their own use of language. The purpose of an essay depends upon the subject matter, whether the author aims is to inform, persuade, explain, or entertain. The essay develops the analytical and intellectual abilities of the writer as well as readers. It evaluates and tests the writing skills of a writer, and organizes his or her thinking to respond personally or critically to an issue. A writer presents his argument in a more sophisticated manner through his essay. In addition, it also encourages readers or students to develop their ability, concepts and skills, to compare and contrast clarity, exposition, conciseness, and persuasion.

This paper is taking into consideration the common characteristics of an essay comparison and contrast, clarity, exposition, conciseness and persuasion with its artistic values of Beauty, Moral and Entertain. To analyze prose style of Frances Bacon in reference to his essays: ("Of Studies", "Of Marriage and single Life", and "Of Revenge"). Francis Bacon is often regarded as the 'Father of English essays'. Bacon's essays have a certain unique characteristic which make us question the classification of essay (Harris, 1996). Literary review through expositional form of writing for presenting facts from his essays: ("Of Studies" Of Revenge" and "Of Marriage and Single Life) and Presenting personal opinion is considered as a method for analyzing of Francis Bacon's Prose Writing Style.

\section{About Francis Bacon}

Francis Bacon (I56I-I626) was one of the most well-known English philosophers in the age of transition from the Renaissance to the early modern era. He has been credited as "Father of English Essays" as well as "Father of Empiricism" (Croll, 20I7). He was influenced by the most influential philosophers of the French Renaissance Michel de Montaigne. Essays are popularized as literary genre by Montaigne. Also unique form of was originated in I6th century by Montaigne's. Bacon borrowed it from him but adopted for his own purpose. Essay form of Bacon are the same with Montaigne, however there is difference in the subject matter where Montaigne's proses are biographical but variety of subjects matter one can find in Bacon's essays (Ratte, I940). One can find in Bacon's essays some qualities of Renaissance as Self-advancement, love for classical learning and natural beauty as he was also influenced of Renaissance. His love of knowledge can be seen in his essay "I have taken all the knowledge to be my province". His admiration of knowledge he says: "Sentia potentia est" which means "knowledge is a power." (Russell, 1979). In his essay "Of Studies", he emphasizes on the advantages of reading stating: "Studies serve for delight, for ornament, and for ability."

Bacon has write about men interested issues and man is the subject of his essays, which is one of the reasons for his essays being popular beside other qualities his work consists. Since human beings are interested in themselves and in this regards his essays have universal appeal. His essays are revolved around three major ideologies: Man in relating to his creator, Man's relation to the world and society and Man relating to him. All these work consist variety of style. The subject of his essays is varied and bears a wide range (Dean, I94I). The universal concepts of life, love, friendship, fortune and death categorized the major subjects of his essays. Bacon through impetrating these themes allude to various types of Latin and other well-crafted phrases for expressing life, nature and nature's mysteries and complexity with distinct style of essays of his era.

\section{Prose Style of Francis Bacon}

Bacon used various styles rather than depending on one style which he adopted it based on his purpose. As a man of renaissance, we find a characteristic of his age: the use of figurative language. Similes and Metaphors and striking comparisons are found in his essays. Mostly he uses two figures of speeches simile and metaphor. His metaphor is mainly drawn from natural, scientific and physical aspects. For example, in the essay Of Studies he writes "Natural abilities like natural plants that needs pruning by studies. The style that he used in thereof essays will go to be analyses each in details.

Bacon's Aphoristic style: Cambridge Advanced Learner's Dictionary defined Aphorism "a short clever saying that is intended to express a general truth." An aphorism is like a proverb which has a quotable quality. Aphorism had been known for a long time and was much respected in his time, but not used as he did as a quality in prose writing. It was found in the Bible in the Book of Proverbs are to be seen in some of the pronouncements of Moses especially in the laws. The aphorism was also to be seen in the writings of the Greek and Latin writers of the Classic times who used it with great effect. The precision of the aphorism for reasoning and persuasive power was accepted in his time. 
His style is most remarkable for its shortness. His talent for shortening sentences, which every sentence in his essays is expected with meaning and has the capability of being extended into several sentences or into paragraph. Many of his sentences seem as proverbs sayings by virtue of their gems of thoughts expressed in a pithy manner. He has said much in fewest words (Knowles, 1998). His essays combine knowledge in thought with great brevity. The short, pithy sayings in his essays have become popular mottoes and household expressions. Bacon in his essays writes in an aphoristic style by making general statements. One can find aphoristic style by reading his essay "Of studies ": as he explaining the importance of study that "study serves for delight, for ornament, and for ability." Bacon states that studies have three purposes it is to delight, for ornament and for ability. He further stated that there are different kinds of books some books are to be tasted, others to be swallowed, and some few to be chewed and digested and so on... He has divided the book into various purpose "Some books are to be tasted, others to be swallowed, and some few to be chewed and digested; that is, some books are to be read only in parts; others to be read, but not curiously; and some few to be read wholly, and with diligence and attention. Some books also may be read by deputy, and extracts made of them by others; but that would be only in the less important arguments and the meaner sort of books, else distilled books are like common distilled waters, flashy things". He further state on importance of reading book speaking about it and writing it have important role as: "Reading marketh a full man; conference a ready man; and writing an exact man." Bacon provides in analytical approaches where he first makes an argument and analyzes it in following sentence. For instance, in "Of studies " Bacon states how studies serve a man and then he explains it: "their chief use for delight, is in privateness and retiring; for ornament, is in discourse; and for ability, is in the judgment and disposition of business. "

Most of the sentences which Bacon uses in "of studies" are short but pregnant with meaning and contains general information as, "Crafty men condemn studies, simple men admire them, and viae men use them." Then suggesting the importance of reading, speaking, and writing, bacon, in the shortest possible words, states: "reading marketh a full man; conference a ready man; and writing an exact man." Almost every sentence in his essays is pregnant with meaning. Ideas are expressed in effective way with memorable qualities: as he states in his essays Of marriage and single life called married man a fortunate "He that hath wife and children hath given hostages to fortune". He also exemplified the prose and cans of married life and single life "Unmarried men are best friends, best masters, best servants, but not always best subjects". He is explaining the role of wives in various stages of lives as "Wives are young men's mistresses, companions for middle age and old men's nurses." in his other essay opposing of talking revenge and says that "This is certain that a man that studied of revenge keeps his own wounds green, which otherwise heal and do well. ("Of Revenge") he also against taking revenge even someone deserves it. He called it wild justice since man become violent in time of taking revenge he states that "Revenge is a kind of wild justice." (Of Revenge) A man takes the revenge on the person by whom he is oppressed. So if he takes revenge, it will be a justice. But at the time when a man takes revenge, he takes it more aggressively than he is oppressed. This is why; Bacon calls the revenge a kind of wild justice. So he suggests us to be detached from taking revenge.

Impersonality: Another significant different in Bacon's essays are that he presenting his argument without being involved himself. He did not reflect his personal opinion and in his writings. He presented his writing through aphoristic style instead his own view points but rather statement of truth where he hides his own identity and true personality. He exemplified his argument by bringing examples from history as using examples of Julius Caesar and Brutus and use of allusion to Latin or Bible in his essays. He detached his personality from his essays by using examples which does not require his personal opinion. Bacon only states these facts as if they are established truths. For example, in "Of studies" he does not give his personal opinion or provide any examples for which books to be read lightly or which to be digested. Through using aphoristic style in his writing, he leaves readers for their own understandings. Bacon uses the aphoristic style to enable the readers as an active participant by allowing them to interpret and give the meanings of his statements. This is opposed to the magisterial style in which all the information is presented making the readers passive and lazy.

Paradox: Bacon used paradox or Antithesis (Greek for "setting opposite", Antithesis can be defined as "a figure of speech involving a seeming contradiction of ideas, words, clauses, or sentences within a balanced grammatical structure. Parallelism of expression serves to emphasize opposition of ideas" ("Literary Devices Paradox",n.d). An antithesis not always contains two ideas within one statement. The ideas do not mean structurally contradictory, yet they serve to be functionally contradictory when comparing two ideas for emphasis. According to Aristotle, the use of an antithesis makes the audience better understand the point the speaker is trying to make (Eden, 20I4). Paradox is used to for the purpose of strengthening an argument trough using either simply contrasting ideas or exact opposites, and can also include both. They make a sentence more memorable for the reader or listener by balance and emphasis of the words. As a crafted man, Bacon very skillfully uses literary device 'paradox' in his essays. As in essay of study he stated that "Studies serve for delight, for ornament and for ability." Also "Some books are to be tasted, others to be swallowed, and some few to be chewed and digested." In other part he states that "Reading maketh a full man, conference a ready man; and writing an exact man." He is giving the Importance of reading that "Read not to contradict, nor to believe, but to weigh and consider." "Of Studies". In his essay of marriage talked about the benefit of being married; "He that hath wife and child hath given hostages to fortune; for they are impediments to great enterprises either of virtue or mischief. Bacon has almost weighing the pros and cons of every question that he makes it. Making 
statement and immediately counter-balances it. He provides the readers with advantages and the disadvantages of a particular issue. Bacon provide picture of both sides. Bacon draws either a definite conclusion after balancing the issues, however most of the time he lifts it to the readers draw their own conclusion from them. For instance, in "Of Marriage and Single life", Bacon presents the advantages of both the states: "Thus, single men are good friends, good masters and good servants, but they are unreliable as good citizens.

Rhetorical Device: Regardless being paradoxical a well-known for terseness and epigrammatic writer Bacon is rhetorical writer as well. His Essays consists argument, the keenness of imagery, analogy and metaphor, which were common features of the time and also highly Latinized. The rhetorical devices have been studied and used by the writers of classics especially, Greek and Roman prose writers and it was practiced at university level for most of examination of the time consist oral rather than written forms. These forms were famous on debates in presence of the teachers' students had to present arguments. It was used for the purpose of persuading or convincing the listener of the correctness of his viewpoint. The same training was given in the Inns of Court where again even the teaching was in the form of debate and argument. It was also famous in legal studies where a set of law court set of Laws was taken by individual and presented and commented upon by the reader and then argued out in its details by the other members of the Bar for the benefit of the students. Becon was a trained lawyer and had special skills of using this device. He has a great power of attracting and persuading his readers. His essays are the finest examples of his persuasion. The rhetorical devices as employed in his essays as well. His essay "Of Studies" Similes and metaphors are used to simplify his ideas into detailed and analytical way. For the purpose of elaborating his view that natural abilities need to be used and bounded by study, Bacon makes use of a simile, rightly emphasizes his point: "........... For natural abilities are like natural plants that need proyning by study."

Bacon's interest in science and scientific accuracy also had a great influence in the formation of his style. In science as in law, it is necessary to divide the material under various heads and to arrange them in due order of preference. His essays show a strong organic unity of structure like a tree with its various branches. With attractive simile taken for Botany he compares human mind to a growing plant. As the growing plants needs to be pruned and watered and manured for prime development, the new growing conscience of us are to be tutored, mounded, oriented and devised by studies. Our natural development which may lead to savagery need to be elaborated with study for the sound growth of personality. He also used metaphor through which learned men are compared to Marshal because like a Marshal's management of his army in the battlefield, learned men plan and keep the general problems of life: "........ and to the plots and marshaling of affairs come best from those that are learned". Also in essay of revenge who persuade people to stopped taking revenge personally as he state that "A man that sudieth revenge, keeps his own wounds green." "Of Revenge" He used extensively metaphors, images, similes and Imagery and Analogy as important devices for persuasion. He takes his imagery from nature and everyday life but his analogies are taken from classical mythology, Bible, astronomy, philosophy, History and the ancient Greek and Roman writers and also from the collection of proverbs Peltonen, M. (1992).

Imagery and Analogy: "Literary Devices" (n.d.) described Imagery is the use figurative language to represent ideas, actions, and object in a way that it appeals to one's physical senses imagery are used in literary text to for the purpose of creating picture of particular words in our mind for its visual representation. The word "imagery" is associated with mental pictures. However, it sometimes it turns out to be more complex than just a picture. It assists the reader's imagination It aids the reader's imagination to visualize the characters and scenes in the literary work clearly. Apart from these mentioned function, images created by using figures of speech like metaphor, simile, personification, and onomatopoeia, serve the function of beautifying a piece of literature. An analogy is comparisons of unlike thigs are ideas, where an idea or a thing is compared to another thing that is quite different from it. It is used in literary text for the purpose of explaining a particular idea or thing by comparing it to something that is familiar. Metaphors and similes are tools used to draw an analogy. Therefore, analogy is more extensive and elaborate than either a simile or a metaphor. The purpose of these devices was to make the words signify actuality or to call up a picture before the eyes of the imagination of the reader. This has a more immediate effect than a purely intellectual approach. Image, metaphor and analogy all perform this function well either in prose or in poetry. Bacon's used extensively brilliant figures of speech taken from familiar objects of nature or from everyday life. His analogies are taken from classical mythology, Bible, astronomy, philosophy, History and the ancient Greek and Roman writers and also from the collection of proverbs (Peltonen, 1992). following are examples taken from his essay "Of studies" "..... natural abilities are like natural plants, that need proyning by study. "..... distilled books are like common distilled waters, flashy things."

Allusion: Allusion is a reference in a literary work to a person, place, or thing in history or another work of literature ("kidskonnect Language Allusion/",(n.d). Allusions are often used to indirect or brief references to well-known characters or events. They are used to summarize broad, complex ideas or emotions in one quick, powerful image. Bacon essays are rich with allusion for illustrating. He draws his allusions, and quotations, from various sources, classical fables, the Bible, History, the ancient Greek and the Roman writers. Which represent and highlight him as learned man? Bacon used them in order to explain his point. Through using allusions, he gives his ideas greater weight and serves to make his point stronger and vivid. During the Renaissance and for long after, these were the sources or terms of reference of the poets and prose writers of Europe. Since these 
were commonly known to all educated people, the references had some meaning and carried with them some emotional and intellectual content or reverberation. Bacon has alluded in his essay, "Of Marriage and Single Life", to Ulysses and a quotation from Thales, an ancient Greek philosopher. He elaborates that loving husband should be serious, conventional and loyal. So, he refers to Ulysses for providing greater impact to his idea and to support his argument. He used allusion as a reference to Penelope, who is the wife of Ulysses, the King of Ithaca and the Greek hero in the Trojan War. She must have grown middle aged by the time Ulysses returned to her after 20 years, at the end of his wanderings and adventures. The allusion here is to the circumstances of Ulysses refusing to marry and live with the goddess Calypso, though she offered to make him immortal like. This allusion more clearly illustrates the topic to the reader that men of a serious bent of mind usually follow conventions and are steady in their love for their wives (Hall, 2008).

In the Essay, Of Revenge, Bacon uses the allusions of Cosmus, Prophet Yousaf A.S) Bacon is giving another reference of his contemporary Shakespeare (Kewes, 2002). He says that the Duke says God orders us to forgive our enemies but never orders us to forgive our friends. If your friends hurt, you than you should definitely take revenge. Through the given reference Bacon emphasis on the importance of taking revenge. Bacon uses allusions to make them fit the occasion. At times the allusions not only support the argument, but are themselves elucidated by the argument. Bacon thus employs allusions and quotations in order to explain his point. They serve to make an impact more scholarly and enrich it while lending weight to his ideas. In the essay "Of Revenge," Solomon is quoted saying that, "It is the glory of a man to pass by an offence". This extraordinary rich frame of reference makes his essays rich and varied and gives us some indication of the knowledge and interests of Bacon. As it has already been suggested his knowledge was almost universal, embracing history and philosophy, geography and science, astronomy and mathematics. Since his knowledge was universal and therefore we have to find some place to respect a man who brings such a weight of information and yet does not impose it upon us, except in stray allusions and references.

\section{Discussion and Conclusion}

Francis Bacon's essays are different in conventional definition of essay as a literary genre. The great contribution of Francis Bacon (I56I-I626) to the development of English prose can hardly be overlooked or denied. Bacon was first scientific philosopher to write English in a clear, lucid and terse style ("mouthshut", n.d) Bacon's works are classified as essays, since they have artistic value for analyzing literary work Beauty, moral. His essays distinct from the current essay as genera of literature (Burtt, 1939). Bacon's sentence structures are craftily varied at various events which show skillful ability of the author. Since his essays are not divided into paragraphs, which seems hard for the reader to get a rapid change from one idea to another. His points are supported by allusion, quotations and analogy of various familiar things. Bacon's style is compact yet polished and indeed some of its conciseness is due to the skillful adaptation of Latin idiom and phrase. "Scrubd Document" (n.d). His essays distinct from other essays as they are usually shorter than what the conventional definition of essay suggests. He detached himself by providing his own perspective and prefers to be objective and select observational forms by using various literary devices (Fish, 197I). His style is very formal (Zeitlin, 1928). His opinion suggests being a statesman or a moralist, not like a street boy (Geertz, 1968). Bacon applied in Essays ("OF Study", "Of Revenge" and "Of Marriage and Single Life") various style and techniques. He used aphoristic style in his essays as explaining general truth having moralistic qualities as proverb. He used Paradox to summarized complex ideas. He used Allusion to support his points and limit his own involvement by referring Bible, Roman writers. He used analogy by using imagery drawn from nature metaphor and simile using comparing unlike things by using familiar objects.

He has adopted the prose style of French Essayist De Montagne for his own purpose. His essays distinct from the current essay as genera of literature. Bacon's essays are often lack coherence. Since his essays are not divided into paragraphs, which seems hard for the reader to get a rapid change from one idea to another. He detached his own involvement and created objectivity by providing opinions and never speaks of himself. He elaborates his point by using analogy, allusion through other literary devices. His opinion suggests being a statesman or a moralist, not like a street boy. Francis Bacon, short and persuasive essay focused on the objective subject-matter of superstition. The lengths of his sentences vary throughout the essay according to the need of the subject. Sentence structures are craftily varied at various events which shows his deft craftsmanship of the author. His points are supported by allusion, quotations and analogy of various familiar things. His sentences express sharp wisdom in the minimum possible words.

Though the different features of Bacon's essays make it difficult to place his writings under the genre of essay. But these features also do not suggest otherwise. So Bacon's works are classified as essays. Francis Bacon have distinctive features which served to his works through the ages. His essays are studied not only for content but for their style respectively. Bacon's style is compact yet polished and indeed some of its conciseness is due to the skillful adaptation of Latin idiom and phrase. He had a great and impressive mastery over the art of saying maximum in minimum words. This achievement was in a great measure due to his formulation of a style to present imaginative eloquence. He was able to present abstract ideas endowed with a kind of life and actuality. 


\section{References}

Brindle, K. \& Gould, M.(2006). Focus on Comprehension I (P.I). Singapore: Learners Publishing

Croll, M. W. (2017). Attic Prose: Lipsius, Montaigne, Bacon. In Landmark Essays on Rhetoric and Literature (pp. I19-I45). Routledge.

Dean, L. F. (I94I). Sir Francis Bacon's Theory of Civil History-Writing. ELH, 8(3), I6I-I83.

Eden, K. (20I4). Poetic and legal fiction in the Aristotelian tradition (Vol. 480). Princeton University Press.

Fish, S. (I97I). Georgics of the Mind: The Experience of Bacon's Essays I. Critical Quarterly, I3(I), 45-70.

Geertz, C. (1968). Thinking as a moral act: Ethical dimensions of anthropological fieldwork in the new states. The Antioch Review, 28(2), 139-I58.

Hall, E. (2008). The return of Ulysses: a cultural history of Homer's Odyssey. IB Tauris.

Harris, W. V. (1996). Reflections on the peculiar status of the personal essay. College English, 58(8), 934-953.

Kewes, P. (2002). Julius Caesar in Jacobean England. The Seventeenth Century, I7(2), I55-I86.

Klarer, M. (20I3). An introduction to literary studies. Routledge. Retrieved from file:///C:/Users/JavePC/Downloads/9780203068915_googlepreview.pdf

Knowles, J. (I998). 'Infinite riches in a little room': Marlowe and the Aesthetics of the Closet. In Renaissance Configurations (pp. 3-29). Palgrave Macmillan, London.

Mill. Burtt, Edwin A. (ed.) (1939). The English Philosophers: From Bacon to Mill. The Modern Library, New York

Mouthshut(n.d).Retrievedfrom https://www.mouthshut.com/search/prodsrch.aspx?type=blogs\&data=bacon

Peltonen, M. (1992). Politics and science: Francis Bacon and the true greatness of states. The Historical Journal, 35(2), 279305.

Ratté, E. H. (1940). A comparison of the essays of Montaigne and Bacon (Doctoral dissertation, Boston University).

Russell, J. (1979). Francis Bacon (p. 55). London: Thames and Hudson.

"Scrubd Document" (n.d). Retrieved from https://www.scribd.com/document/375988994/FRANCIS-BACON

Zeitlin, J. (1928). The Development of Bacon's Essays: With Special Reference to the Question of Montaigne's Influence upon Them. The Journal of English and Germanic Philology, 27(4), 496-5I9.

\section{Copyrights}

Copyright for this article is retained by the author(s), with first publication rights granted to the journal. This is an open-access article distributed under the terms and conditions of the Creative Commons Attribution license (http://creativecommons.org/licenses/by/4.0/). 